\title{
Quality Characteristics of Frankfurters Formulated with Apricot Pomace Obtained from Apricot Juice Processing
}

\author{
Çilem Purma Adıbelli ${ }^{1}$, Meltem Serdaroğlu ${ }^{2 *}$ \\ ${ }^{l}$ Istanbul Directorate of Provincial Food Agriculture and Livestock-Caddebostan Distrct, 34728 Kadlköy/Istanbul, Turkey \\ ${ }^{2}$ Food Engineering Department, Engineering faculty, Ege University, 35100 Bornova/Izmir, Turkey \\ A R T I C LE IN F O \\ Research Article \\ Received 29 September 2016 \\ Accepted 09 January 2017 \\ Keywords: \\ Sausages \section{A B S T R A C T} \\ In this study the effects of dried apricot pomace (AP) on the technological, nutritional and \\ sensory quality of frankfurters were investigated. Frankfurters formulated with 5\% AP \\ showed better quality compared to the addition of 10 and $15 \%$ AP. Protein and fat content \\ decreased as the concentration of added AP was over 5\%. AP addition resulted in lower \\ $\mathrm{pH}$ and energy values. Frankfurters formulated with AP had higher cooking and process \\ yield values. AP addition resulted with decrement in lightness and increment in \\ yellowness of samples. 5\% addition of AP resulted in good sensory scores. The results \\ indicate that apricot pomace could be an effective functional ingredient in emulsion type \\ meat products.
}

Frankfurter

Dietary fiber

Apricot

Emulsion

*Corresponding Author:

E-mail: meltem.serdaroglu@ege.edu.tr

\section{Introduction}

Fruits and vegetables occupy an important role in human nutrition as they provide essential minerals, vitamins, dietary fiber and phenolic compounds that are natural antioxidants (Grigelmo-Miguel et al., 1999a). Extension of meat and meat products with vegetables, fruits, and their fibers could reduce production costs and improve the technological and nutritional quality. However, the relevance of fruits and vegetables in the processing of meat products relates to their functional properties such as water binding, fat emulsification, yield and sensory properties.

Garcia et al. (2002) investigated the cereal and fruit fibers in dry fermented sausages and reported that, fruit fibers gave the best results particularly orange fiber was beneficial in keeping the sensory properties. Sausages with the addition of $2.5 \%$ and $5 \%$ raw lemon albedo and $2.5 \%, 5 \%$ and $7.5 \%$ cooked albedo showed sensory properties similar to conventional sausages (Ferna'ndezGine's et al., 2004).

The use of peach dietary fiber as a fat substitute could be a good alternative to offer both low fat and high dietary fiber meat products since it has a high water binding capacity (Grigelmo-Miguel et al., 1999b). Besides their fibers, various fresh or dried vegetable and fruits have been used in low fat meat products as a filler and fiber source.
Good colour development, high scores for appearance and flavour have been reported by Fista et al. (2004) for Greek traditional sausages formulated with $24 \%$ leek. Addition of $2 \%$ carrot and $10 \%$ spinach improved the oxidative stability of poultry hamburgers (Pizzocaro et al., 1998). The sensory quality of the hamburgers remains good up to dried tomato peel concentrations of $4.5 \%$ (w/w) (García et al., 2009). Kimchi powder at a level of $2 \%$ increased emulsion stability and improved cooking characteristics of breakfast sausages ( Lee et al., 2008). It has been showed that $5 \%$ or $10 \%$ plum puree improved cooking characteristics of beef patties without any detrimental effects on sensory properties (Yildiz-Turp and Serdaroglu, 2010). Low fat pork sausage with tomato powder up to $1.5 \%$ was found to be well acceptable up to 30 days at refrigerated storage (Kim et al., 2011). Guava powder increased dietary fiber, reduced emulsion stability in chicken nuggets (Verma and Sahoo, 2000). The addition of up to $15 \%$ date paste to the formulation of bologna- type products was shown to enhance the nutritional and technological quality together with a satisfactory sensory quality (Sánchez-Zapata et al., 2011).

Turkey is the leading fresh and dried apricot producer in the World and produced about 811.609 metric ton apricot annually (FAO, 2015). Some part of the harvest is processed to obtain apricot juice. Therefore, apricot juice 
processing produces a considerable amount of byproducts, unfortunately, these by-products are generally used in animal feeding or fertilizer. To the best of our knowledge, only limited research is available regarding the functional and technological characteristics of apricot pomace. However apricot pomace could also be useful to the food industry as a source of functional ingredient due to its fiber content and phenolic compounds. The objectives of this study were to characterize the functional properties of apricot pomace and to evaluate the possible use of dried apricot pomace in frankfurter type sausages.

\section{Materials and methods}

\section{Apricot Pomace (AP) Preparation}

Frozen apricot pomace (waste of apricot juice production) was supplied from a fruit juice company (Anadolu Etap Penkon Gıda ve Tarım Ür. AŞ. Mersin Turkey ). After defrosting at $4^{\circ} \mathrm{C}$ for $24 \mathrm{~h}$, pomace was washed ( $4 \mathrm{~L}$ of water per $1 \mathrm{~kg}$ ), then pressed to drain excess water and dried to $9 \%$ moisture at $50^{\circ} \mathrm{C}$ in a drum drier. A grinder mill (Brook Crompton Series 2000, UK) was used to obtain a fine powder.

\section{Frankfurter Formulation and Processing}

Standard manufacturing practices and equipment were used in frankfurter processing. Formulations were calculated to yield a $7 \mathrm{~kg}$ batch. Base ingredients were lean beef $(70.5 \%$ moisture, $24.9 \%$ protein, $3.6 \%$ fat and $1.1 \%$ ash) and beef fat. Frankfurters were manufactured according to a standart formulation; $80 \%$ lean beef, $20 \%$ beef fat, $15 \%$ ice flake, $4 \%$ corn starch, $2.5 \%$ sodium chloride, $500 \mathrm{mg} / \mathrm{kg}$ sodium tripolyphosphate, $500 \mathrm{mg} / \mathrm{kg}$ sodium ascorbate, $150 \mathrm{mg} / \mathrm{kg}$ sodium nitrite and $2 \%$ spices. This standart formulation was used as a control sample (no added apricot pomace) and for the other formulations AP was added at a level of 5, 10 or $15 \%$.

Frankfurter batter was prepared by initially chopping lean meat with one half of the ice and curing ingredients in a silent cutter (Alpina-SG Schweiz, Suffolk,UK) for 4 min to extract salt soluble proteins and then fat, spices, corn starch and AP together with the reminder ice were added and the batter was chopped for $8 \mathrm{~min}$ more, total processing time was 12 minutes.

The batter was filled into $15 \mathrm{~cm}$ long and $1.2 \mathrm{~cm}$ diameter collagen casings and clipped both sides (FV20.84'/305, E2-Sign, EPECH-Neutre plisse) and placed into a smoking chamber (Afos Mini Kiln,Hull, UK)) and dried at $40^{\circ} \mathrm{C}$ for $1 \mathrm{~h}$ then smoked at $40^{\circ} \mathrm{C}$ for $45 \mathrm{~min}$. Frankfurters were then heat processed at $80^{\circ} \mathrm{C}$ water to a core temperature of $73^{\circ} \mathrm{C}$. After cooking process frankfurters were showered with cold water, vacuum packed in polyethylene bags and stored at $4^{\circ} \mathrm{C}$ for 5 months.

Physicochemical analyses carried on dried apricot pomace

Water absorption capacity (WAC) was determined according to Mac Connell et al., (1974). One gram of sample was stirred with $15 \mathrm{ml}$ of distilled water in a $50 \mathrm{ml}$ centrifuge tube and soaked overnight at room temperature. Then the mixture was centrifuged at $15,000 \times \mathrm{g}$ for $15 \mathrm{~min}$. The free water was discarded and the absorbed water was weighted. WAC was expressed as the gram of water per gram of dry powder.

Oil absorption capacity (OAC) determined by using modified method of Lin et al. (1974). $1 \mathrm{~g}$ AP was mixed with $10 \mathrm{ml}$ sunflower oil in a centrifuge tube. The content was stirred for $30 \mathrm{~min}$ in the vortex mixer, then tubes were centrifuged at $4^{\circ} \mathrm{C}$ for $10 \mathrm{~min}$ with $3000 \mathrm{~g}$. The supernatant was removed with a pipette and tubes were inverted for $25 \mathrm{~min}$ to drain the oil and the residue weighed (Wr). The OAC was expressed as grams of oil bound per gram of the sample on a dry basis. OAC was calculated by the equation given below.

$$
\mathrm{OAC}(\mathrm{g} / \mathrm{g})=\mathrm{Wr} / \mathrm{Wi}
$$

Where Wi was the sample weight (g)

The swelling capacity (SC) was determined according to Guillon and Champ (2000). One gram of sample was weighed in a graduated cylinder and left to swell overnight at room temperature after adding $15 \mathrm{ml}$ of distilled water. SC was expressed as $\mathrm{ml}$ of swollen sample per gram of dry initial matter. $\mathrm{pH}$ measurement was carried out according to Lee et al. (2008). $10 \mathrm{~g}$ of AP was mixed with $100 \mathrm{ml}$ distilled water and then $\mathrm{pH}$ was measured.

\section{Proximate Analysis and pH of Frankfurter Samples}

Protein, moisture, and ash content were analyzed following AOAC (2000) procedures. Fat content was determined according to Flynn and Bramblett (1975). $\mathrm{pH}$ was measured directly (WTW pH meter, Germany) by using a glass electrode (Landvogt, 1991).

\section{Energy Value}

Total calories (kcal) were calculated in relation to samples of $100 \mathrm{~g}$ using the Atwater values corresponding to fat $(9 \mathrm{kcal} / \mathrm{g})$, protein $(4.02 \mathrm{kcal} / \mathrm{g})$ and carbohydrates (3.87 kcal/g). Caloric value of SDF (soluble dietary fibre) was estimated to be $2 \mathrm{kcal} / \mathrm{g}$.

\section{Production Yield}

The weight of samples after filling and after cooling were recorded and production yield was expressed as a percentage difference between the raw and cooked weights.

\section{Jelly and Fat Separation}

Jelly and fat separation was measured as described by Bloukas and Honikel (1992). Pre-weighed glass jars were filled with $200 \mathrm{~g}$ frankfurter batter, then closed and cooked at $90^{\circ} \mathrm{C}$ in a water bath for $35 \mathrm{~min}$. Jars were cooled under tap water then stored at $4^{\circ} \mathrm{C}$ for $24 \mathrm{~h}$ to facilitate the fat and jelly separation. After warming up the jars in a water bath at $45^{\circ} \mathrm{C}$ for $1 \mathrm{~h}$, the fluid in each jar was collected into a volumetric cylinder. The fluid jelly and fat, separated in the volumetric cylinder, were measured in $\mathrm{ml}$ and calculated as a percent of the original weight of batter. The mean value of three jars was taken for each treatment. 


\section{Expressible Moisture}

A filter press technique was used to determine expressible moisture of cooked frnkfurters (Zayas and Lin, 1998). Measurements were carried on 4 samples for each treatment.

\section{Purge Loss}

Purge loss was determined according to Bloukas et al. (1997). Samples were patted dry with paper towel, weighed and packaged under vacuum. After the storage at $4^{\circ} \mathrm{C}$ for 7 days, frankfurters were removed from the package, again patted dry and reweighed. Purge loss was determined from the difference in weights between the two measurements expressed as a percentage of initial weight. The mean value of three sample packages was taken for each treatment.

\section{Consumer Cooking Loss}

The samples were cut into $3 \mathrm{~cm}$ pieces and cooked in a pre- heated electric grill (Arçelik, İstanbul) 3 min for each surface. The difference before and after weights was recorded and total cooking loss was calculated. Measurements were carried on 4 samples for each treatment.

\section{Colour}

Colour parameters of $L^{*}$ (lightness), $a^{*}$ (redness) and $b^{*}$ (yellowness) on the inner and the outer surfaces of frankfurters were measured using a colour difference meter (Chroma Meter CR-300, Konica Minolta, Sensing, Inc., Sakai, Japan). Ten samples from each treatment were analyzed, and the average value was determined by taking observations from five different locations on a given sample.

\section{TBARS Analysis}

2-Thiobarbituric acid reactive substances (TBARS) were determined on freshly prepared samples $\left(0^{\text {th }}\right.$ day) and stored samples $\left(60^{\text {th }}\right.$ days of storage at $\left.4^{\circ} \mathrm{C}\right)$ according to Kirk and Sawyer (1991). Sample absorbance was measured spectrophotometrically (Cary 50 Bio, UV Vis Spectrophotometer, Varian Instruments, Australia). A conversion factor of 7.8 was used for the calculation of TBARS. Each sample was analyzed in duplicate and results were expressed as 2-thiobarbituric acid reactive substances (TBARS) as $\mathrm{mg}$ malonaldehyde (ma)/kg sample.

\section{Texture Evaluation}

Elasticity, hardness, and puncture resistant were measured using Instron Universal Testing Machine (Model 1140, Minnesota, USA) after 24 h of production. Measurements were made on $1.5 \mathrm{~cm}$ height and $1.75 \mathrm{~cm}$ diameter frankfurters. $3.5 \mathrm{~cm}$ diameter rod, $0.75 \mathrm{~cm}$ compression height and $20 \mathrm{~kg}$ force were used for analysis. $200 \mathrm{~mm} / \mathrm{min}$ cross-head speed and $500 \mathrm{~mm} / \mathrm{min}$ writer speed were chosen. Measurements were carried on 4 samples for each treatment.

\section{Sensory evaluation}

Samples from each formulation were randomly assigned for sensory evaluation after $24 \mathrm{~h}$ of production. $2.5 \mathrm{~cm}$ samples were fried in pre-heated Teflon pan for 3 minutes and served warm to a 8 member panel. At each session, three samples were served immediately to panellists and were subjected to sensory evaluation for appearance, juiciness, texture, flavour intensity and overall acceptability. Samples were evaluated by using a 9-point hedonic scale ( $1=$ dislike extremely, $2=$ dislike very much, 3=dislike moderately, 4=dislike slightly, 5=neither like nor dislike, $6=$ like slightly, $7=$ like moderately, $8=$ like very much, 9=like extremely). The mean score for each attribute is reported. Water and bread were served to cleanse the mouth between the samples.

\section{Statistical Analysis}

The data was analysed by one way and two way ANOVA by using the SPSS software version (SPSS, 2000). Differences $(P<0.05)$ among the means were compared using Duncan's Multiple Range test.

\section{Results and Discussion}

\section{Functional Properties and $\mathrm{pH}$ of Apricot Pomace}

The apricot pomace (AP) showed a WAC value of 1.2 $\mathrm{g}$ water/g sample. When comparing the WAC reported in our study with other fruit pomaces it is comparable with AP (1.62-1.87 g water/g sample) (Figuerola et al., 2005) and lower than peach pomace (9.2-12.1 g water/g sample) (Grigelmo-Miguel et al., 1999a) and pineapple pomace (5.32g water/g sample) (Selania et al., 2014). These differences could be due to fruit species and processing methods. AP had a value of $2.3 \mathrm{~g}$ oil $/ \mathrm{g}$ sample OAC. Ingredients with a high OAC allow the stabilization of high fat food products and emulsions (Kuntz, 1994). OAC was comparable with those found in the literature for pineapple pomace (Selania et al., 2014) and pear pomace (Aguedo et al., 2012). AP had $3.4 \mathrm{ml} / \mathrm{g} \mathrm{SC}$. SC was lower than those of pear and apple pomace $(7.0-5.9 \mathrm{ml} / \mathrm{g}$ ) reported by (Aguedo et al., 2012). pH of AP was recorded as 4.9 .

\section{Proximate Analysis, $p H$ and Energy Value}

The proximate composition, $\mathrm{pH}$ and energy values of frankfurters are presented in Table 1. Moisture content changed from 55.27 to $56.25 \%$, protein levels ranged 15.46 to $16.68 \%$, moreover fat content changed 15.58 to $18.03 \%$ and ash content changed 2.13 to $2.33 \%$. Incorporation of AP slightly affected the chemical composition of the final product $(\mathrm{P}<0.05)$ which was in agreement with Lee et al. (2008) who reported a small effect in chemical composition with the addition of kimchi powder in the formulation of breakfast sausages. Fat and protein contents of sausages were within the limits of the Turkish Sausage Standard (TSE, 2016). The $\mathrm{pH}$ values of the frankfurters ranged from 5.95 to 6.13 . $\mathrm{AP}$ addition decreased $\mathrm{pH}$ values $(\mathrm{P}<0.05)$ of frankfurter samples, this decrement in $\mathrm{pH}$ could be attributed to the acid nature of AP ( $\mathrm{pH} 4.9)$. Similar results were reported 
previously (Eyiler and Öztan, 2011; Kim et al., 2011) in sausages formulated with different amounts of tomato powder and raw pork burgers formulated with passion fruit albedo (López-Vargas et al., 2014). However, Savadkoohi et al. (2014), reported no changes in $\mathrm{pH}$ values of sausages formulated with tomato pomace. According to Turkish Food Codex legislation, the highest $\mathrm{pH}$ value of frankfurter type sausages should be 6.40 (Anonymous, 2000). The $\mathrm{pH}$ values of frankfurters in this study were in the limits that indicated in legislation.

As expected, decreasing levels of fat content with the addition of AP resulted lower energy values $(\mathrm{p}<0.05)$, frankfurters formulated with $15 \%$ AP had the lowest energy value. Similar results were obtained by Turhan et al. (2005) for meatballs formulated with hazelnut pellicle. Garcia et al. (2002) obtained 35\% reductions in energy value of fermented sausages with added fruit fiber.

\section{Hydration and Binding Properties}

Functional properties have been correlated with the quality of fiber source. Processes such as grinding, drying, heating or extrusion cooking, might modify the physical properties of the fiber matrix and also affect the hydration properties (Femenia et al., 2000). Results regarding the processing yield, jelly and fat separation, consumer cooking loss and expressible moisture are given in Table 2.

Process yield is a practical method for determining the weight loss of meat products during processing steps such as cooking and smoking (Candoğan and Kolsarıc1, 2003a). Process yield varied between 90.8-93.7\% and the addition of 10 or $15 \%$ AP increased process yield of frankfurters $(\mathrm{P}<0.05)$. Process yield has been reported between 80 to $98 \%$ for low fat frankfurters (Candoğan and Kolsarıc1, 2003b; Luruena et al., 2004; JiménezColmenero et al., 2005).

Ingredient based fibers increase process yield of meat products, by holding more water in their structure. The increase in process yield with AP addition due to less cook loss during processing can be attributed to improvement of the hydration and binding properties of the product. It is likely that the major contribution to water binding was due to its high dietary fiber content and thus high water absorption.

Jelly and fat separation values changed between 9.7 to $11.5 \%$ (Table 2). Separation of jelly and fat from frankfurter batters was higher in 15\% AP added samples than the other treatment groups, that could be explained by the decrease in protein content may affect emulsification capacity. Since the most important factor that affects the water holding capacity of emulsion type meat products is the protein content when protein content increases, the polypeptide location that can be interact with heat process increases and causes a stabile gel matrix (Pietrasik, 1999). This property provides an increment in water and fat binding capability. Y1lmaz (2004) pointed out that the suitable amount of rye bran added to low-fat meatballs was no more than $10 \%$. Contradictory findings obtained in which vegetable and fruit powders were incorporated in meat products resulted in good binding properties (Lee et al., 2008).

Loss of water from meat products after thermal processing negatively affects quality parameters such as tenderness, juiciness, texture and flavour. Consumer cooking loss ranged between 8.4 to $10.3 \%$ (Table 2), AP addition resulted decrement $(\mathrm{P}<0.05)$ in consumer cooking loss. Since AP has water and oil absorption capacity due to its soluble and insoluble components, decrement in cooking loss due to AP addition appears to be related to its fat and water binding capacity. Similar results have been reported by the addition of kimchi powder (Lee et al, 2008) and plum puree (Y1ldiz-Turp and Serdaroğlu, 2010) increased cooking yield in meat products.

Expressible water content changed between 41.4$49.6 \%$ (Table 2). WHC referred to the ability of a given structure to prevent water from being released, thus a lower amount of expressible water reflected a greater WHC. The results from the present study demonstrated that expressible moisture of samples added with $15 \%$ AP showed better performance on holding water in frankfurters $(\mathrm{P}<0.05)$.

Table 1 Chemical composition, $\mathrm{pH}$ and energy values of frankfurter samples

\begin{tabular}{l|cccccc}
\hline Samples & Moisture $\%$ & Protein $\%$ & Fat $\%$ & Ash \% & pH & Energy (kcal/100g) \\
\hline CON & $56.3^{\mathrm{a}} \pm 0.03$ & $16.7^{\mathrm{c}} \pm 0.76$ & $18.0^{\mathrm{b}} \pm 1.01$ & $2.1^{\mathrm{a}} \pm 0.01$ & $6.13^{\mathrm{d}} \pm 0.04$ & $229.3^{\mathrm{c}} \pm 0.99$ \\
$5 \mathrm{AP}$ & $55.7^{\mathrm{a}} \pm 0.98$ & $16.7^{\mathrm{c}} \pm 0.71$ & $17.1^{\mathrm{b}} \pm 0.76$ & $2.1^{\mathrm{a}} \pm 0.08$ & $6.07^{\mathrm{c}} \pm 0.99$ & $221.1^{\mathrm{bc}^{\mathrm{c}} \pm 0.01}$ \\
$10 \mathrm{AP}$ & $55.9^{\mathrm{a}} \pm 0.65$ & $15.9^{\mathrm{b}} \pm 0.08$ & $16.2^{\mathrm{a}} \pm 0.03$ & $2.3^{\mathrm{a}} \pm 0.11$ & $6.02^{\mathrm{b}} \pm 0.22$ & $209.4^{\mathrm{b}} \pm 0.43$ \\
$15 \mathrm{AP}$ & $55.3^{\mathrm{a}} \pm 0.09$ & $15.5^{\mathrm{a}} \pm 0.76$ & $15.6^{\mathrm{a}} \pm 0.32$ & $2.3^{\mathrm{a}} \pm 0.99$ & $5.95^{\mathrm{a}} \pm 0.11$ & $202.4^{\mathrm{a}} \pm 0.87$ \\
\hline
\end{tabular}

a-b means within a column with different letters are significantly different, AP: Apricot pomace, CON: Frankfurters formulated without AP, 5AP: Frankfurters formulated with 5\% AP, 10AP: Frankfurters formulated with 10\% AP, 15AP: Frankfurters formulated with 15\% AP

Table 2 Hydration and binding properties of frankfurter samples

\begin{tabular}{l|cccc}
\hline Samples & Cooking loss $(\%)$ & Process yield $(\%)$ & Jelly and fat separation $(\%)$ & Expressible moisture $(\%)$ \\
\hline CON & $10.3^{\mathrm{c}} \pm 0.98$ & $90.8^{\mathrm{a}} \pm 1.12$ & $9.7^{\mathrm{a}} \pm 0.65$ & $83.1^{\mathrm{d}} \pm 0.87$ \\
$5 \mathrm{AP}$ & $10.0^{\mathrm{c}} \pm 0.05$ & $90.8^{\mathrm{a}} \pm 0.05$ & $9.8^{\mathrm{a}} \pm 0.21$ & $81.3^{\mathrm{c}} \pm 0.77$ \\
$10 \mathrm{AP}$ & $9.1^{\mathrm{b}} \pm 1.22$ & $92.8^{\mathrm{b}} \pm 0.98$ & $9.7^{\mathrm{a}} \pm 0.76$ & $80.0^{\mathrm{b}} \pm 0.21$ \\
\hline $15 \mathrm{AP}$ & $8.4^{\mathrm{a}} \pm 0.98$ & $93.7^{\mathrm{b}} \pm 0.22$ & $11.5^{\mathrm{b}} \pm 0.09$ & $78.2^{\mathrm{a}} \pm 0.65$ \\
\hline
\end{tabular}

a-b Means within a column with different letters are significantly different, AP: Apricot pomace, CON: Frankfurters formulated without AP, 5AP: Frankfurters formulated with 5\% AP, 10AP: Frankfurters formulated with 10\% AP, 15AP: Frankfurters formulated with 15\% AP 
Table 3 Purge loss during storage

\begin{tabular}{l|ccccc}
\hline Samples & $1^{\mathrm{st}}$ month & $2^{\text {nd }}$ month & $3^{\text {rd }}$ month & $4^{\text {th }}$ month & $5^{\text {th }}$ month \\
\hline CON & $0.5^{\mathrm{cC}} \pm 0.02$ & $0.7^{\mathrm{bC}} \pm 0.8$ & $2.6^{\mathrm{aB}} \pm 0.1$ & $5.5^{\mathrm{aA}} \pm 0.09$ & $5.6^{\mathrm{aA}} \pm 0.32$ \\
$5 \mathrm{AP}$ & $0.9^{\mathrm{bC}} \pm 0.65$ & $1.4^{\mathrm{aB}} \pm 0.76$ & $1.4^{\mathrm{bB}} \pm 1.2$ & $5.3^{\mathrm{aA}} \pm 0.24$ & $5.4^{\mathrm{aA}} \pm 0.91$ \\
$10 \mathrm{AP}$ & $1.3^{\mathrm{aB}} \pm 0.98$ & $1.6^{\mathrm{aB}} \pm 0.11$ & $1.7^{\mathrm{aB}} \pm 0.05$ & $1.8^{\mathrm{bB}} \pm 0.54$ & $3.4^{\mathrm{bA}} \pm 0.87$ \\
$15 \mathrm{AP}$ & $1.5^{\mathrm{aB}} \pm 0.67$ & $1.7^{\mathrm{aB}} \pm 0.65$ & $1.8^{\mathrm{aB}} \pm 0.01$ & $1.9^{\mathrm{bB}} \pm 0.87$ & $3.0^{\mathrm{bA}} \pm 0.65$ \\
\hline
\end{tabular}

a-b Means within a column with different letters are significantly different, AP: Apricot pomace, CON: Frankfurters formulated without AP, 5AP: Frankfurters formulated with 5\% AP, 10AP: Frankfurters formulated with 10\% AP, 15AP: Frankfurters formulated with $15 \%$ AP

Table 4 Outer $\mathrm{L}^{*}, \mathrm{a}^{*}, \mathrm{~b}^{*}$ values of frankfurter samples during storage

\begin{tabular}{|c|c|c|c|c|c|c|}
\hline Samples & $0^{\text {th }}$ day & $1^{\mathrm{st}}$ month & $2^{\text {nd }}$ month & $3^{\text {rd }}$ month & $4^{\text {th }}$ month & $5^{\text {th }}$ month \\
\hline \multicolumn{7}{|c|}{$\mathrm{L}^{*}$} \\
\hline $\mathrm{CON}$ & $51.3^{\mathrm{aF}} \pm 0.88$ & $56.2^{\mathrm{bB}} \pm 1.87$ & $53.5^{\mathrm{dE}} \pm 1.98$ & $57.9^{\mathrm{aA}} \pm 0.98$ & $54.3^{\mathrm{dC}} \pm 0.76$ & $53.8^{\mathrm{bD}} \pm 0.09$ \\
\hline $5 \mathrm{AP}$ & $48.5^{\mathrm{cE}} \pm 0.43$ & $56.2^{\mathrm{bB}} \pm 0.76$ & $55.1^{\mathrm{cD}} \pm 0.76$ & $56.6^{\mathrm{cA}} \pm 0.09$ & $55.1^{\mathrm{cD}} \pm 1.22$ & $56.0^{\mathrm{aC}} \pm 0.01$ \\
\hline $10 A P$ & $48.7^{\mathrm{bE}} \pm 0.76$ & $57.1^{\mathrm{aA}} \pm 0.87$ & $56.1^{\mathrm{aC}} \pm 1.65$ & $56.9^{\mathrm{bB}} \pm 1.32$ & $57.2^{\mathrm{aA}} \pm 0.97$ & $55.6^{\mathrm{cD}} \pm 0.06$ \\
\hline $15 \mathrm{AP}$ & $47.6^{\mathrm{dF}} \pm 0.43$ & $56.1^{\mathrm{bB}} \pm 0.98$ & $55.5^{\mathrm{bD}} \pm 0.65$ & $55.9^{\mathrm{dC}} \pm 1.98$ & $56.4^{\mathrm{bA}} \pm 0.07$ & $51.4^{\mathrm{dE}} \pm 0.76$ \\
\hline \multicolumn{7}{|c|}{$\mathrm{a}^{*}$} \\
\hline $\mathrm{CON}$ & $12.4^{\mathrm{a} A} \pm 1.32$ & $13.5^{\mathrm{A}} \pm 0.43$ & $13.7^{\mathrm{A}} \pm 0.08$ & $13.3^{\mathrm{A}} \pm 0.76$ & $13.0^{\mathrm{A}} \pm 0.87$ & $13.4^{\mathrm{A}} \pm 0.87$ \\
\hline $5 \mathrm{AP}$ & $11.0^{\mathrm{bB}} \pm 1.23$ & $13.8^{\mathrm{A}} \pm 0.66$ & $13.0^{\mathrm{A}} \pm 0.65$ & $13.2^{\mathrm{A}} \pm 0.43$ & $13.8^{\mathrm{A}} \pm 0.54$ & $13.0^{\mathrm{A}} \pm 0.76$ \\
\hline $10 \mathrm{AP}$ & $12.7^{\mathrm{aA}} \pm 0.43$ & $12.5^{\mathrm{A}} \pm 1.09$ & $13.3^{\mathrm{A}} \pm 0.54$ & $13.2^{\mathrm{A}} \pm 0.44$ & $13.8^{\mathrm{A}} \pm 0.43$ & $12.9^{\mathrm{A}} \pm 0.11$ \\
\hline $15 \mathrm{AP}$ & $12.2^{\mathrm{aA}} \pm 0.32$ & $12.7^{\mathrm{A}} \pm 1.21$ & $12.9^{\mathrm{A}} \pm 0.43$ & $12.9^{\mathrm{A}} \pm 0.54$ & $13.0^{\mathrm{A}} \pm 0.32$ & $12.5^{\mathrm{A}} \pm 0.43$ \\
\hline \multicolumn{7}{|c|}{$\mathrm{b}^{*}$} \\
\hline $\mathrm{CON}$ & $17.9^{\mathrm{dA}} \pm 0.55$ & $17.1^{\mathrm{dC}} \pm 0.32$ & $16.6^{\mathrm{dD}} \pm 0.34$ & $17.2^{\mathrm{dB}} \pm 0.32$ & $17.3^{\mathrm{dB}} \pm 0.32$ & $17.2^{\mathrm{dB}} \pm 0.34$ \\
\hline $5 \mathrm{AP}$ & $19.7^{\mathrm{bA}} \pm 0.66$ & $19.0^{\mathrm{cAB}} \pm 0.11$ & $18.7^{\mathrm{cC}} \pm 0.01$ & $18.8^{\text {c. }} \pm 0.32$ & $18.9^{\mathrm{cB}} \pm 1.32$ & $18.7 \pm 0.11^{\mathrm{cC}}$ \\
\hline $10 \mathrm{AP}$ & $18.9^{\mathrm{cD}} \pm 0.01$ & $20.6^{\mathrm{bC}} \pm 0.23$ & $20.8^{\mathrm{bB}} \pm 0.02$ & $20.6^{\mathrm{bC}} \pm 0.32$ & $20.8^{\mathrm{bB}} \pm 1.11$ & $21.6^{\mathrm{aA}} \pm 0.09$ \\
\hline $15 \mathrm{AP}$ & $21.4^{\mathrm{aE}} \pm 0.02$ & $22.2^{\mathrm{aC}} \pm 0.99$ & $22.9^{\mathrm{aB}} \pm 0.32$ & $22.0^{\mathrm{aD}} \pm 0.01$ & $23.1^{\mathrm{aA}} \pm 1.23$ & $21.0 \pm 0.32^{\mathrm{bF}}$ \\
\hline
\end{tabular}

Purge loss from vacuum packaged frankfurters during storage are seen in Table 3. Storage time and AP addition significantly affected $(\mathrm{P}<0.05)$ purge loss. Releasing water in packages increased with the increasing storage period in all formulations. On the $1^{\text {st }}$ and $2^{\text {nd }}$ months increasing AP concentration resulted in an increment in purge loss, however on $4^{\text {th }}$ and $5^{\text {th }}$ months AP addition resulted in lower purge loss. On $4^{\text {th }}$ and $5^{\text {th }}$ months, the highest purge loss was found for control and 5AP samples. Obtained data showed that the matrix formed in those meat and fiber networks had a greater ability to entrap water than that control. Purge loss reducing effect of AP might be due to the stability of pectin content. Candoğan and Kolsarıc1 (2003b) reported the purge loss reducing effect of pectin gel in low fat frankfurters during storage. Proteins which provide the emulsion should loss their ability to bind water with time so increment in purge loss was recorded for all samples with increasing storage time. The increase in purge loss with storage time was in agreement with the findings of Bloukas and Paneras (1993) and Candoğan and Kolsarıc1 (2003b) in low-fat frankfurters.

\section{Colour}

Color is one of the main parameters determining consumer acceptance of meat products. In reformulated products, there is a strong relation between colour parameters, fat, water, and pigment contents. Outer $L^{*}, a^{*}$ and $b^{*}$ values of samples are seen in Table 4. AP addition and storage period significantly affected $L^{*}$ values
$(\mathrm{P}<0.05)$ on the $1^{\text {st }}$ and $2^{\text {nd }}$ and $4^{\text {th }}$ months of storage. $L^{*}$ values increased with the increasing amounts of AP. The addition of AP resulted in dilution of cured pigment and less intense colour. During the storage period, there was a significant decrement in $L^{*}$ values of 10AP and 15AP samples, Frankfurters added 5\% AP had more stable colour during storage period than other treatments. This suggests that AP losses colour with increasing storage period and as a result samples become darker. Kim et al. (2011) reported that changes in colour parameters in frankfurters formulated with tomato powder related to the added amount. Storage period and AP addition did not affect $(\mathrm{P}>0.05)$ outer redness ( $a^{*}$ value) of samples, $a^{*}$ values changed between 12.9 to 13.4 on the $1^{\text {st }}$ month of storage and changed between 12.9 to 13.4 at the end of the storage period. Yellowness $\left(b^{*}\right.$ values) increased with increasing AP concentration, this increment in $b^{*}$ values could be due to the carotenoids present in apricot pomace. Choi et al. (2009) reported that meat batters with added rice bran had lower lightness and redness values and higher yellowness than control samples. These results are consisted with those obtained by other researchers (Lee et al., 2008; Viuda-Martos et al., 2010a). While storage time did not affect $b^{*}$ values of control and 5AP samples $(\mathrm{P}>0.05)$ increment in yellowness with storage time was only significant for $10 \mathrm{AP}$ and $15 \mathrm{AP}$ samples $(\mathrm{P}<0.05)$. This suggests that there was an interference between the effects produced by these ingredients in meat matrix which can be affected by storage. 
Table 6 Textural parameters of frankfurter samples

\begin{tabular}{l|ccc}
\hline Samples & Elasticity $(\mathrm{cm})$ & $\underline{\text { Hardness }(\mathrm{kg})}$ & $\underline{\text { Puncture resistant }(\mathrm{kg})}$ \\
\hline CON & $0.3^{\mathrm{d}} \pm 0.43$ & $15.0^{\mathrm{b}} \pm 1.09$ & $15.7^{\mathrm{b}} \pm 1.32$ \\
$5 \mathrm{AP}$ & $0.21^{\mathrm{c}} \pm 0.65$ & $15.3^{\mathrm{b}} \pm 0.11$ & $15.2^{\mathrm{b}} \pm 0.98$ \\
$10 \mathrm{AP}$ & $0.13^{\mathrm{b}} \pm 0.33$ & $14.4^{\mathrm{b}} \pm 0.65$ & $15.0^{\mathrm{b}} \pm 0.32$ \\
$15 \mathrm{AP}$ & $0.07^{\mathrm{a}} \pm 1.22$ & $9.7^{\mathrm{a}} \pm 0.21$ & $9.4^{\mathrm{a}} \pm 1.09$ \\
\hline
\end{tabular}

a-b Means within a column with different letters are significantly different, AP: Apricot pomace, CON: Frankfurters formulated without AP, 5AP:

Frankfurters formulated with 5\% AP , 10AP: Frankfurters formulated with 10\% AP , 15AP: Frankfurters formulated with 15\%AP

Table 7 TBARS values of Frankfurters $(\mathrm{mg} \mathrm{ma} / \mathrm{kg})$

\begin{tabular}{l|cc}
\hline Samples & $0^{\text {th }}$ day & $60^{\text {th }}$ day \\
\hline CON & $0.45^{\mathrm{bB}} \pm 0.32$ & $0.50^{\mathrm{bA}} \pm 0.11$ \\
$5 \mathrm{AP}$ & $0.55^{\mathrm{aA}} \pm 0.21$ & $0.57^{\mathrm{aA}} \pm 0.08$ \\
$10 \mathrm{AP}$ & $0.52^{\mathrm{abB}} \pm 0.91$ & $0.59^{\mathrm{aA}} \pm 0.96$ \\
$15 \mathrm{AP}$ & $0.37^{\mathrm{cB}} \pm 0.65$ & $0.60^{\mathrm{aA}} \pm 0.09$ \\
\hline
\end{tabular}

a-b Means within a column with different letters are significantly different, A-D Means within a row with different letters are significantly different, AP: Apricot pomace, CON: Frankfurters formulated without AP, 5AP: Frankfurters formulated with 5\% AP , 10AP: Frankfurters formulated with $10 \%$ AP , 15AP: Frankfurters formulated with 15\% AP

Table 8 Sensory properties of frankfurter samples

\begin{tabular}{|c|c|c|c|c|}
\hline \multirow{2}{*}{ Properties } & \multicolumn{4}{|c|}{ Samples } \\
\hline & $\mathrm{CON}$ & $5 \mathrm{AP}$ & $10 \mathrm{AP}$ & $15 \mathrm{AP}$ \\
\hline Appearance & $7.2^{\mathrm{b}} \pm 0.22$ & $6.8^{\mathrm{b}} \pm 1.07$ & $6.8^{\mathrm{b}} \pm 0.43$ & $5.9^{\mathrm{a}} \pm 0.72$ \\
\hline Juiciness & $6.8^{c} \pm 0.44$ & $5.8^{\mathrm{ab}} \pm 0.42$ & $5.9^{\mathrm{ab}} \pm 0.65$ & $5.3^{\mathrm{a}} \pm 1.11$ \\
\hline Texture & $6.9^{c} \pm 0.02$ & $6.3^{\mathrm{bc}} \pm 2.1$ & $5.2^{\mathrm{ab}} \pm 0.11$ & $3.6^{\mathrm{a}} \pm 1.09$ \\
\hline Flavour intensity & $7.1^{\mathrm{c}} \pm 0.03$ & $6.7^{\mathrm{b}} \pm 0.09$ & $6.3^{\mathrm{ab}} \pm 0.43$ & $5.8^{\mathrm{a}} \pm 1.01$ \\
\hline Overall acceptability & $7.0^{\mathrm{b}} \pm 0.32$ & $6.4^{\mathrm{ab}} \pm 0.11$ & $6.3^{\mathrm{ab}} \pm 0.76$ & $5.8^{\mathrm{a}} \pm 0.21$ \\
\hline
\end{tabular}

a-b means within a column with different letters are significantly different, AP: Apricot pomace, CON: Frankfurters formulated without AP, 5AP:

Frankfurters formulated with 5\% AP , 10AP: Frankfurters formulated with 10\% AP , 15AP: Frankfurters formulated with 15\% AP

Inner colour parameters can be seen in Table 5. AP addition generally decreased $L^{*}$ and increased $\mathrm{b}^{*}$ values $(\mathrm{P}<0.05)$ however had no effect on $\mathrm{a}^{*}$ values of samples $(\mathrm{P}>0.05)$. Fernandez-Gines et al. (2004) reported that increase of albedo concentration reduced lightness in Bolognas. Similar results were taken by Mittal and Barbut (1996) for carboxymethyl cellulose added group had lower lightness values than other groups. GrigelmoMiguel et al. (1999b) obtained that $\mathrm{a}^{*}$ values of frankfurters with peach dietary fiber were increased with increasing fiber content. $L^{*}$ and $b^{*}$ values of Frankfurter samples affected by storage period, due to the purge loss and interference between the ingredients in meat matrix resulted slightly decrement in $L^{*}$ and $b^{*}$ values of Frankfurter samples.

\section{Texture evaluation}

The addition of dietary fibers to foods modifies the texture and stability in ways determined by the processing conditions, but the mechanisms differ depending on the solubility of the fibers. Insoluble fibers can influence food texture (Thebaudin et al., 1997).

Table 6 shows the effect of AP addition on textural properties of frankfurter samples. Results indicated that AP significantly affected $(\mathrm{P}<0.05)$, the textural properties, comparing the control it could be observed that hardness, elasticity, and puncture resistant values were lower for the frankfurters formulated with AP. The addition of AP resulted in less hard and chewy texture than the control. The decrease in hardness and puncture resistance values could be explained by the presence of $15 \%$ AP damaged protein -water and protein-protein gel network. Similarly, Claus and Hunt (1991) found that using $3.5 \%$ oat fiber caused a decrease in elasticity values of the sausages. Kim et al. (2011) reported a marked decrease in springiness values when tomato powder added to sausages at a level of $1.5 \%$. The decrement in hardness with the addition AP is not desirable because hardness is an important textural attribute in the determination of acceptable sausages (Pereira et al., 2011). Depending on the amount and type of fiber, controversial results have been reported on hardness, both hardening and softening in texture have been observed when the fiber is added to various cooked meat products (Serdaroğlu et al., 2005; Viuda-Martos et al., 2010b; López-Vargas et al., 2014). The addition of AP at a level of 10 or $5 \%$ did not cause any negative effect on the texture properties of Frankfurters. Reported findings have been contradictory for various reasons, but it has generally been found that the addition of different kinds of fiber (soy, wheat, cereal and fruit) to cooked meat emulsions increase hardness (Ferna'ndez-Gine's et al., 2005; Jiménez Colmenero et al., 2005; Cofrades et al., 2008;)

\section{TBARS Values}

Lipid oxidation is one of the main limiting factors for the quality and acceptability of meat and meat products (Kanner, 2004). Table 7 shows in TBARS values on $0^{\text {th }}$ and $60^{\text {th }}$ days. Initial TBARS values changed between $0.37-0.55 \mathrm{mg} \mathrm{ma} / \mathrm{kg}$. During storage TBARS values of 
Frankfurters increased significantly except 5AP samples. $\mathrm{AP}$ at a level of $5 \%$ demonstrated antioxidant activity. On $60^{\text {th }}$ day TBARS values were $0.50 \mathrm{mg} \mathrm{ma} / \mathrm{kg}$ for the control, $0.57,0.59$, and $0.60 \mathrm{mg} \mathrm{ma} / \mathrm{kg}$ for $5 \%, 10 \%$, and $15 \%$ AP added samples. All frankfurter samples had TBARS values within acceptable limits. Verma and Sahoo (2013) indicated malonaldehyde concentrations between 1000 and $2000 \mu \mathrm{g} / \mathrm{kg}$ were threshold values for rancidity.

The phenolics compounds present in apricot may be the reason for its antioxidant ability. Hydroxycinnamic acids such as cafferic, B coumaric and ferulic acids and their esters are the most common phenolics in apricot. Akbulut and Artık (2002) reported that $(+)$ - catechin is the most common phenolics in the apricot cultivars which dry well in Turkey.

Other authors have reported the antioxidant potential of naturally occurring plant extracts rich in phenolic compounds when incorporated in cooked meat products (Nuñez de Gonzalez et al., 2009; Y1ld1z-Turp and Serdaroğlu, 2010; López-Vargas et al., 2014).

\section{Sensory Evaluation}

Sensory evaluation results are presented in Table 8, to evaluate appearance and colour of all samples, attributes of homogenous appearance and typical frankfurter colour (pink colour) were considered. 15\% AP addition caused a decrease in appearance and colour scores, other treatments had similar scores with control. The decrease in colour scores may be because samples containing high AP concentration showed an increase in the light brown shade as the amount of carotenoid pigment and dilution of cured pigment.

Control samples had the highest scores for juiciness. AP addition caused a decrease $(\mathrm{P}<0.05)$ in juiciness which could be related to the proportional reduction of meat and fat in Frankfurter formulation, juiciness is the total mouth feel of both fat and water. Fernandez-Gines et al. (2004) had similar results for bologna sausages with lemon albedo. AP addition at a level of $15 \%$ decreased flavor intensity that could be due to a masking effect of AP upon meaty odor perception.

Garcia et al. (2002) had similar results in their research using different fruit and cereal fibers and different fat ratios used in fermented sausages. In the case of texture, the results obtained were as expected due to those obtained with the instrumental analysis. Increasing AP concentration in Frankfurter formulation resulted decrement in texture scores $(\mathrm{P}<0.05), 15 \%$ AP added frankfurters had lowest texture scores. Similar to our results Lee and Ahn (2005) reported that incorporated turkey breast roll with dried plum extract decreased hardness scores. AP addition resulted softening in texture, similarly, Garcia et al. (2009) reported that texture scores decreased in burgers formulated with $6 \%$ dry tomato peel. The samples to which $5 \%$ or $10 \%$ AP had been added were best appreciated by the panellists.

\section{Conclusion}

As a conclusion, the results obtained in this study show that apricot pomace successfully add (until 10\%) to emulsion type meat products such as frankfurters. Using of 5 or $10 \%$ apricot pomace improved cooking properties and had no negative effect on the physical and sensory properties assessed of frankfurters.

\section{References}

Aguedo M, Kohnen S, Rabetafika N, Bossche SV, Sterckx J, Blecker C, Beauve C, Paquot, M. 2012. Composition of byproducts from cooked fruit processing and potential use in food. J. Food Comp. Anal. 27: 61-69

Akbulut M, Artık N. 2002. Phenolic compounds profile of apricot and wild apricot fruits and their changes during the process. In Proceedings of 7 th Food Congress in Turkey, Ankara, Turkey.

Anonymous 2000. Turkish Food Codex Legislation No:2000/4 Republic of Turkey Ministry of Agricultural Rural Affairs, Ankara.

AOAC. 2000. Official Methods of Analysis (17th ed.) Association of Official Agricultural Chemists, Arlington.

Bloukas I, Honikel KO. 1992. The influence of additives on the oxidation of pork back fat and its effect on water and fat binding in finely comminuted batters. Meat Sci. 32: 31-43.

Bloukas JG, Paneras ED. 1993. Substituting olive oil for pork back fat affects quality of low-fat frankfurters. J. Food Sci. 58: 705709.

Bloukas JG, Paneras ED, Fournitz GC. 1997. Sodium lactate and protective culture effects on quality characteristics and shelf life of low-fat frankfurters produced with olive oil. Meat Sci. 45: 223-238.

Candogan K, Kolsarıc1 N. 2003a. The effects of carrageenan and pectin on some quality characteristics of low-fat beef frankfurters. Meat Sci. 64: 199-206

Candogan K, Kolsarıcı N. 2003b. Storage stability of low-fat beef frankfurters formulated with carrageenan or carrageenan with pectin. Meat Sci. 64: 207-214

Choi YS, Choi JH, Han DJ, Kim HY, Lee MA, Kim HW. Jeong JY, Kim JC. 2009. Characteristics of low-fat meat emulsion systems with pork fat replaced by vegetable oils and rice bran fiber. Meat Sci.. 82: 266-271

Claus JR, Hunt MC. 1991. Low-fat, high-added water bologna formulated with texture-modifying ingredients. J. Food Sci. 56: 643-647.

Cofrades S, López-López I, Solas MT, Bravo L, JiménezColmenero F. 2008. Influence of different types and proportions of added edible seaweeds on characteristics of low-salt gel/emulsion meat systems. Meat Sci. 79: 767-776.

Eyiler E, Öztan A. 2011. Production of Frankfurters with tomato powder as the natural additive. LWT- Food Science and Technology. 44:307-311

FAO. 2015, Agricultural Statistics, http://faostat.fao.org/, December, 2015

Femenia A, Bestard MJ, Sanjuan N, Rossello C, Mulet A. 2000. Effect of rehydration temperature on the cell wall components of broccoli (Brassica oleracea L. Var.) plant tissues. J. Food Eng. 46: 157-163.

Ferna'ndez-Gine's J M, Ferna'ndez-Lo'pez J, Sayas-Barbera E, Sendra E. Pe'rez-A'lvarez JA. 2004. Lemon albedo as a new source of dietary fiber: Application to bologna sausages. Meat Sci. 67:7-13.

Ferna'ndez-Gine's JM, Ferna'ndez-Lo'pez J, Sayas-Barbera E, Pe'rez- A'lvarez JA. 2005. Meat products as functional foods: A review. J. Food Sci. 70: 37-43.

Fernández-López J, Fernández-Ginés JM , Aleson-Carbonell L, Sendra E, Sayas-Barberá E, Pérez-JA Alvarez .2004. Application of functional citrus by-products to meat products. Trends Food Sci. Tech. 15:176-185 
Figuerola F, Hurtado ML, Estévez AM, Chiffelle IG. 2005. Fibre concentrates from apple pomace and citrus peel as potential source for food enrichment. Food Chem. 91:395-401

Fista GA, Bloukas JG, Siomos AS. 2004. Effect of leek and onion on processing and quality characteristics of Greek traditional sausages. Meat Sci. 68:163-172.

Flynn AW, Bramblett VD. 1975. Effects of frozen storage cooking method and muscle quality and attributes of pork loins. J. Food Sci. 40: 631-633.

Garc1'a ML, Dominguez R, Galvez MD, Casas C, Selgas MD. 2002. Utilization of cereal and fruit fibres in low fat dry fermented sausages. Meat Sci. 60, 227-236.

García ML, Calvo MM, Dolores,M. and Selgas, MD. (2009). Beef hamburgers enriched in lycopene using dry tomato peel as an ingredient. Meat Science. 83: 45-49

Grigelmo-Miguel N, Gorinstein S, Martín-Belloso O. 1999b. Characterization of peach dietary fiber concentrate as a food ingredient. Food Chem. 65: 175-181.

Grigelmo-Miguel N, Abadias-Seros MI, Martin-Belloso O. 1999a. Characterization of low-fat high-dietary fiber frankfurters. Meat Sci. 52: 247-256.

Guillon F, Champ M. 2000. Structural and physical properties of dietary fibres, and consequences of processing on human physiology. Food Res. Int. 33: 233-245.

Jiménez Colmenero F, Ayo MJ, Carballo J. 2005. Physicochemical properties of low sodium frankfurter with added walnut: effect of transglutaminase combined with caseinate, $\mathrm{KCl}$ and dietary fibre as salt replacers. Meat Sci. 69: 781-788

Jiménez- Colmenero F, Ayo MJ, Carballo J. 2005. Physicochemical properties of low sodium frankfurter with added walnut: effect of transglutaminase combined with caseinate, $\mathrm{KCl}$ and dietary fibre as salt replacers. Meat Sci. 69: 781-788

Kanner J. 2004. Oxidative processes in meat and meat products: Quality implications. Meat Sci. 36, 169:189

Kim LS, Jin SK, Mandal PK, Kang SN. 2011. Quality, S.N. of lowfat pork sausages with tomato powder as colour and functional additive during refrigerated storage. J. Food Sci. Tech. 48: 591597

Kirk RS, Sawyer R. 1991. Pearson's Composition and Analysis of Foods, 9th ed. . UK: Longman Scientific and Technical, 708730.

Kuntz LA. 1994. Fiber: From frustration to functionality. Food Product Design. 91, 108-116

Landvogt A. 1991. Errors in pH measurement of meat and meat products by dilution effects. In In Proceedings, 37th International Congress of Meat Science and Technology, Kulmbach, Germany.

Lee E J, Ahn DU. 2005. Quality characteristics of irradiated turkey breast rolls formulated with plum extract. Meat Sci. 71: 300-305.

Lee MA, Han DJ, Jeong JY, Choi JH, Choi YS, Kim HY, Paik, HD, Kim CJ. 2008. Effect of kimchi powder level and drying methods on quality characteristics of breakfast sausage. Meat Sci. 80: 708-714.

Lin MJY, Humbert ES, Souslky FW. 1974. Certain functional properties of sunflower meal products. J. Food Sci. 39: 368-370

López-Vargas JH, Fernández-López J, Pérez-Álvarez JA, ViudaMartos M. 2014. Quality characteristics of pork burger added with albedo-fiber powder obtained from yellow passion fruit (Passiflora edulis var. flavicarpa) co-products. Meat Sci. 97: 270-276

Luruena-Martinez MA, Vivar-Quintana AM, Revilla I. 2004. Effect of locust bean/xanthan gum addition and replacement of pork fat with olive oil on the quality characteristics of low-fat frankfurters. Meat Sci. 68: 383-389

Mac Connell AA, Eastwood A, Mitchell WD. 1974. Physical characterization of vegetable foodstuffs that could influence bowel function. J. Sci. Food Agric. 25: 1457-1464
Mittal GS, Barbut S. 1996. Effects of three cellulose gums on the texture profile and sensory properties of low fat frankfurters. Int. J. Food Sci. Tech. 31: 241-247

Nuñez de Gonzalez MT, Hafley BS, Boleman RM, Miller RK, Rhee KS, Keeton JT. 2009. Qualitative effects of fresh and dried plum ingredients on vacuum packaged, sliced hams. Meat Sci. 83: $74-81$.

Pereira AGT, Ramos MR, Teixeira JT, Cardoso GP, Ramos ALS, Fontes PR. 2011. Effects of the addition of mechanically deboned poultry meat and collagen fibers on quality characteristics of frankfurter-type sausages. Meat Sci. 89: 519525

Pietrasik Z. 1999. Effect of content of protein, fat and modified starch on binding textural characteristics, and color of comminuted scalded sausages. Meat Sci. 51: 17-25

Pizzocaro F, Senesi E, Veronese P, Gasparolo A. 1998. Mechanically deboned poultry meat hamburgers. II. Protective and antioxidant effect of the carrot and spinach tissues during frozen storage. Ind. Alim. 37: 710-720

Sánchez-Zapata E, Fernández-López J, Peñarandam M, FuentesZaragoza E, Sendra E, Sayas Pérez-Alvarez JA. 2011. Technological properties of date paste obtained from date byproducts and its effect on the quality of a cooked meat product. Food Res. Int. 44: 2401-2407

Savadkoohia S, Hoogenkampb H, Shamsic K, Farahnakya A. 2014. Colour, sensory and textural attributes of beef frankfurter, beef ham and meat-free sausage containing tomato pomace. Meat Sci. 97: 410-418

Selania MM, Brazacaa SGC, Diasb CTS, Ratnayakec WS, Floresc RA, Bianchinic A. 2014. Characterisation and potential application of pineapple pomace in an extruded product for fibre enhancement. Food Chem. 163:23-30

Serdaroglu M. Y1ldı-Turp G, Kiyalbek A. 2005. Quality of low-fat meatballs containing Legume flours as extenders. Meat Sci. 70: 99-105

SPSS. 2000. Release 8 for Windows. (Chicago, IL, SPSS).

Thebaudin JY, Lefebvre AC. Harrington M, Bourgeois CM. 1997. Dietary fibres: Nutritional and technological interest. Trends Food Sci. Tech. 8: 41-48.

TSE. 1071 Sosis Standardı (Turkish Sausage Standard, TS 980) Ankara; Turkish Standarts Institute, (2000).

Turhan S, Sagir I, Ustun N S. 2005. Utilization of hazelnut pellicle in low-fat beef burgers. Meat Sci. 71: 312-316.

Verma SP, Sahoo J. 2000. Improvement in the quality of ground chevon during refrigerated storage by tocopherol acetate preblending. Meat Sci. 56: 403-413.

Verma AK, Rajkumar V, Banerjee R, Biswas S, Das AK. 2013. Guava (Psidium guajava L). Powder as an Antioxidant Dietary Fibre in Sheep Meat Nuggets. Asian-Australasian. J.Anim. Sci. 26: 886-895 Viuda-Martos M, Ruiz-Navajas Y, FernándezLópez Y, Pérez-Álvarez JA. 2010a. Effect of adding citrus fiber washing water and rosemary essential oil on the quality characteristics of a bologna sausage. LWT - Food Sci. Tech. 43: 958-963

Viuda-Martos M, Ruiz-Navajas Y, Fernández-López J, PérezÁlvarez JA. 2010b. Effect of added citrus fibre and spice essential oils on quality characteristics and shelf-life of mortadella. Meat Sci. 85: 568-576

Yıldız-Turp G, Serdaroğlu M. 2010. Effects of using plum puree on some properties of low fat beef patties. Meat Sci. 86: 896-900.

Yilmaz I. 2004. Effects of rye bran addition on fatty acid composition and quality characteristics of low-fat meatballs. Meat Science. 67, 245-249

Zayas FJ, Lin CS. 1998. Quality characteristics of frankfurters containing corn germ protein. J. Food Sci. 53: 1587-1591. 